Erudition and the Republic of Letters 


\section{Erudition and the Republic of Letters}

Editor-in-Chief

Mordechai Feingold, California Institute of Technology

\section{Associate Editor}

Carol Magun

\section{Editorial Board}

Ann Blair, Harvard University

Anthony T. Grafton, Princeton University

Alastair Hamilton, The Warburg Institute

James Hankins, Harvard University

Herbert Jaumann, Universität Greifswald

Dmitri Levitin, Oxford University

Anthony Ossa-Richardson, University College, London

William Poole, Oxford University

Jean-Louis Quantin, Ecole Pratique des Hautes Etudes

Jessica L. Wolfe, The University of North Carolina at Chapel Hill

Volumes published in this journal are listed on brill.com/erl 


\section{Erudition and the Republic of Letters}

VOLUME 7 (2022)

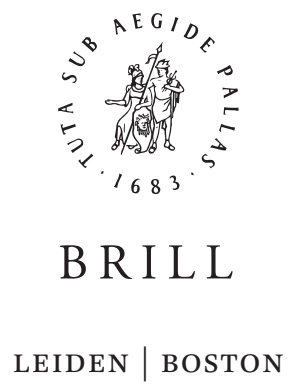




\section{Instructions to Authors}

Manuscripts for submission, books for review and editorial inquiries and proposals should be sent to Erudition and the Republic of Letters, Dr. Mordechai Feingold, Division of the Humanities and Social Sciences, California Institute of Technology (Caltech), 1200 East California Boulevard, Pasadena, ca 91125 usa, e-mail: feingold@hss.caltech.edu. Submissions may also be sent to our online submission system at http://www.editorial-manager.com/erl.

Articles must be original work and should not have been publishes previously. Simultaneous submission of identical work to other journals is not acceptable. All articles will be refereed. Authors who wish to facilitate blind reviews should avoid referring to their own works with first person possessive pronouns and include a first, separate page with title, name, affiliation (if any), and a short abstract in English. It is the author's responsibility, if she or he is planning a submission in English and is not a native speaker, to have her or his text checked over and/or polished by a native speaker prior to submission: otherwise it can be rejected if the syntax is too poor.

Submissions in 12 pt. Times New Roman, left margin justification, including epigraphs, quotations and endnotes are requested. American punctuation and spelling are preferred. All articles should be preceded by an abstract in English of 150 words maximum.

Additional Instructions to Authors can be found at our website: www.brill.com/erl. The additional Instructions to Authors also include details on how to publish on an Open Access basis using Brill Open.

Brill Open Access options can be found at brill.com/openaccess.

This publication has been typeset in the multilingual "Brill" typeface with over 5100 characters covering Latin, IPA, Greek and Cyrillic, this typeface is especially suitable for use in the humanities. For more information, please see brill.com/brill-typeface.

ISSN 2405-5050

E-ISSN 2405-5069

Copyright 2022 by Koninklijke Brill NV, Leiden, The Netherlands.

Koninklijke Brill NV incorporates the imprints Brill, Brill Nijhoff, Brill Hotei, Brill Schöningh, Brill Fink, Brill mentis, Vandenhoeck \& Ruprecht, Böhlau Verlag and V\&R Unipress.

All rights reserved. No part of this publication may be reproduced, translated, stored in a retrieval system, or transmitted in any form or by any means, electronic, mechanical, photocopying, recording or otherwise, without prior written permission from the publisher. Requests for re-use and/or translations must be addressed to Koninklijke Brill NV via brill.com or copyright.com.

Brill has made all reasonable efforts to trace all rights holders to any copyrighted material used in this work. In cases where these efforts have not been successful the publisher welcomes communications from copyright holders, so that the appropriate acknowledgements can be made in future editions, and to settle other permission matters.

This journal is printed on acid-free paper and produced in a sustainable manner. 